\title{
THE ANALYSIS OF BANKING GOVERNANCE IN INDONESIA: THE FINANCIAL SERVICES AUTHORITY PERSPECTIVE
}

\author{
Rudy Hartanto ${ }^{1}$ Pupung Purnamasari ${ }^{1}$ \\ ${ }^{1}$ Prodi Akuntansi FEB Universitas Islam Bandung, Indonesia \\ Email : rudyhartanto05@gmail.com \\ Email :p purnamasari@yahoo.co.id
}

\begin{tabular}{|c|c|}
\hline INFO ARTIKEL & ABSTRAK/ABSTRACK \\
\hline $\begin{array}{l}\text { Histori Artikel : } \\
\text { Tgl. Masuk : } 08 \text { Februari } 2019 \\
\text { Tgl. Diterima: } 01 \text { Maret } 2019 \\
\text { Tersedia Online: } 29 \text { Maret } \\
2019 \\
\text { Keywords: } \\
\text { good corporate governance, } \\
\text { self assessment, financial } \\
\text { service authority regulation }\end{array}$ & $\begin{array}{l}\text { The purpose of this study is to examine the factors that } \\
\text { influence the ranking of banking governance in Indonesia. } \\
\text { This study uses the perspective of regulatory authority of } \\
\text { financial services concerning self-assessment of bank } \\
\text { governance as regulated in Regulation of Financial } \\
\text { Services Authority Number (POJK). The data in this study } \\
\text { using the report of banking governance in } 2014-2017 \text { with a } \\
\text { sample obtained as many as } 294 \text { banks. Hypothesis testing } \\
\text { technique is done by using ordinal regression analysis. The } \\
\text { results showed that the variable owner, ROA, asset, and } \\
\text { status have a positive effect on GCG. In contrast, the } \\
\text { leverage in this study showed a negative influence on GCG. } \\
\text { Testing the growth and age does not affect the level of } \\
\text { banking governance }\end{array}$ \\
\hline
\end{tabular}

\section{PENDAHULUAN}

Krisis keuangan ditahun 1997-1998 yang terjadi baik di tingkat global dan nasional di Indonesiaterjadi dikarenakan adanya implementasi tata kekola perusahaan yang lemah. Adanya krisis tersebut mendorong Indonesia melakukan penguatan ekonomi ditingkat nasional atuapun regional dengan penerapan tata kelola yang baik. Awal mula penerapan tata kelola yang baik yaitu dilakukan dengan melakukan perjanjian antara Indonesia dengan International Monetary Fund (IMF) dengan membentuk Komite Nasional Corporate Governance (KNKCG) pada tahun 1999. (Wibowo, 2010).

Pada tahun 2004 KNKCG berubahn naga menjadi Komite Nasional Kebijakan Governance (KNKG). Sejak pendiriannya, KNKG telah mengeluarkan beberapa pedoman yang terkait dengan Corporate Governance (CG), termasuk pedoman umum Good Corporate Governance di Indonesia. Pedoman tersebut berisi hal hal yang dapat menjadi landasan bagi perusahaan yang ingin mempertahankan kesinambungan usahanya dalam jangka panjang dalam koridor etika bisnis yang berlaku (Komite Nasional Kebijakan Governance, 2006).

Seiring dengan pertumbuhan sektor keuangan yang ada di Indonesia termasuk perbankan yang bergerak di bidang jasa keuangan (gambar 1), maka perlu dukungan tata kelola yang baik untuk sektor keuangan agar dapat menghindari default risk ((Ali, Liu, \& Su, 2018). Pada tahun 2014, KNKG telah merespon pertumbuhan perbankan tersebut dengan mengeluarkan Pedoman Good Corporate Governance Perbankan Indonesia. Selain itu, Otoritas Jasa Keuangan (OJK) selaku otoritas keuangan di Indonesia yang bertugas mengawasi, melindungi, dan mengatur jasa keuangan di Indonesia pada tahun 2014 juga menerbitkan Roadmap Tata Kelola Peusahaan Indonesia. Roadmap tersebut berisi mengenai 33 (tiga puluh tiga) rekomendasi yang mencakup semua aspek dari prinsipprinsip tata kelola yang baik. 


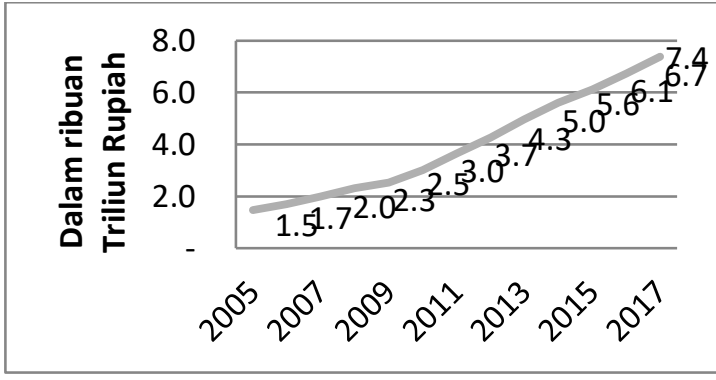

Sumber: Statistik Perbankan Indonesia, Otoritas Jasa Keuangan

Gambar 1. Pertumbuhan Aset Perbankan Tahun 2005-2017

Pada tahun 2017 OJK menerbitkan peraturan Peraturan Otoritas Jasa Keuangan Nomor (POJK) Nomor 55 Tahun 2017 dan Surat Edaran Otoritas Jasa Keuangan (SEOJK) Nomor 13 Tahun 2017 Tentang Penerapan Tata Kelola bagi bank umum. POJK dan SEOJK tersebut merupakan peralihan dari aturan yang sebelumnya telah diatur oleh Peraturan Bank Indonesia (PBI) mengenai Surat Edaran BI Nomor 15 Tahun 2013 Perihal Pelaksanaan Good Corporate Governance Bagi Bank Umum. Pedoman dan aturan mengenai GCG di perbankan dikeluarkan tidak lain dengan tujuan agar terciptanya bank dan sistem perbankan yang sehat.

POJK tersebut berisi mengenai kewajiban agar perbankan menyusun dan menyampaikan laporan tata kelola bank yang bersangkutan. Salah satu kewajiban isi laporan tata kelola tersebut adalah adanya penilaian sendiri (selfasssesment) atas tata kelola perbankan yang akan diotoritasi oleh OJK. Tujuan adanya penilaian sendiri adalah untuk memastikan perbankan telah menerapkan prinsip dasar tata kelola yang baik yang terdiri atas transparansi, akuntanbilitas, pertanggungjawaban, independensi dan kewajaran. penerapan prinsip tata kelola yang baik.
Tingkat penilaian sendiri atas tata kelola perbankan berdasarkan POJK tersebut dibagi kedalam peringkat faktor tata kelola dari angka 1 sampai dengan 5 , dimana semakin kecil peringkat maka menunjukkan semakin baik tata kelola perbankan. Peringkat faktor tata kelola dilakukan dengan berpedoman pada matriks peringkat faktor tata kelola yang telah diatur dalam lampiran II SE OJK Nomor 13 Tahun 2017 Tentang Penerapan Tata Kelola Bagi Bank Umum.

Perkembangan terhadap kesadaran penerapan tata kelola perusahaan tidak lepas dari adanya keterlibatan lembaga, praktisi dan atau akademisi dalam melakukan kajian baik dari pembuatan indeks ataupun rangking serta penelitian mengenai tata kelola perusahaan. Perkembangan penelitian mengenai tata kelola perusahaan dinegara berkembang mengalami minat yang cukup signifikan (Al-Bassam, 2018). Hal tersebut dapat dilihat dari adanya Corporate Governance Perception Index (CGPI) yang diterbitkan pada tahun 2001. GCPI merupakan riset dan pemeringkat GCG diperusahaan publik yang tercatat di BEI.

CGPI paling sering digunakan sebagai referensi dalam beberapa penelitian mengenai GCG di Indonesia (Baskoro, 2017; Darmawati, 2006; Larastomo, Perdana, Triatmoko, \& Sudaryono, 2016; Nuswandari, 2009; Pamungkas, 2013; Ramadhani, Andreas dan Desmiyawati, 2015; Suharna dan Swandari, 2017).Selain GCPI, pengukuran lain yang digunakan dalam penelitian GCG adalah dengan menggunakan mekanisme GCG (Irmalasari, 2010; Wijayanti, 2012), GCG dengan pengukuran melalui beberapa proksi yang berupa dualitas CEO, ratio dari non ekseutif direktur, kepemilikan direktur, remunerasi direktur dan jumlah shareholders (Makki dan Lodhi, 2014; 
Wijayanti, 2012) serta menggunakan skor GCG berdasarkan Pedoman Umum Good Corporate Governance dan Basel Committee tahun 2006 (Hikmah dkk., 2011). Beberapa penelitian di luar negeri mengenai GCG sebagian besar menggunakan pengukuran rating GCG yang dibuat oleh lembaga-lembaga independen (Ariff dkk., 2007; Bauer dkk., 2004; Brown dan Caylor, 2006; Klapper dan Love, 2002; Waweru, 2014; AlBassam, 2018; Cunha dan Rodrigues, 2018; Puri dan Kumar, 2018).

Beberapa penelitian mengenai GCG di sektor perbankan saat ini masih terbatas menggunakan sampel perbankan yang telah listing di BEl. Beberapa penelitian yang dilakukan tersebut menunjukkan hasil yang beragam (Hikmah dkk., 2011; Pamungkas, 2013; Sihombing dan Pangaribuan, 2017). Pada penelitian yang dilakukan diluar negeri menunjukkan hasil bahwa tata kelola perbankan berbeda dengan perusahaan non financial dalam beberapa aspek seperti struktur dewan komisaris dan kompensasi CEO. Perbedaan tersebut bisa terjadi karena adanya peraturan dan hukum (R. B. Adams, 2009).

Sihombing dan Pangaribuan (2017) melakukan penelitian struktur GCG perbankan dengan hasil yang menunjukkan bahwa struktur GCG yang baik akan meningkatkan penungkapan GCG yang lebih baik. Hasil dari penelitianpenelitian tersebut dapat disimpulkan bahwa masih belum adanya penelitian GCG yang menggunakan peraturan GCG yang telah ada di Indonesia. Secara tidak langsung GCG sebenarnya mencakup sistem hukum, aturan, dana peraturan disuatu negara (Gillan dan Starks, 2003).

Berdasarkan penjelasan diatas dapat disimpulkan bahwa penelitian mengenai GCG masih terbatas menggunakan pengukuran skor dan pedoman yang diterbitkan oleh lembaga independen dan masih terbatas pada sampel perbankan yang telah listing di BEl. Adanya hal tersebut maka cakupan penelitian ini difokuskan pada analisis mengenai perkembangan dan faktor yang mempengaruhi GCG perbankan secara keseluruhan baik listing maupun non listing berdasarkan POJK tentang penerapan tata kelola bank umum. Analisis penelitian ini menggunakan regulasi tata kelola bank yang ada dapat dinilai lebih tepat dikarenakan regulasi merupakan bagian hukum dalam pelaksanaan suatu aktivitas negara/organisasi. Fokus utama penelitian ini adalah menggunakan tingkat skor pengungkapan GCG yang diwajibkan di laporkan dalam laporan tata kelola perbankan.

\section{KERANGKA TEORITIS DAN PENGEMBANGAN HIPOTESIS}

\section{Konsep Dasar dan Praktik Tata Kelola}

Konsep tata kelola untuk pertama kali diperkenalkan dalam laporan Cadburry pada tahun 1992. Laporan tersebut menyebutkan bahwa tata kelola merupakan sistem dimana perusahaan diarahkan dan dikendalikan dimana setiap fungsi dalam perusahaan memiliki tanggungjawab masing-masing baik dari dewan direksi, pemegang saham, direktur maupun auditor (Cadbury, 1992). Tata kelola perusahaan atau yang lebih dikenal dengan Good Corporate Governance (GCG) memiliki makna yang lebih luas dikarenakan mencakup ilmu yang lintas sektoral (Wibowo, 2010) dan merupakan bagian dari sistem hukum, aturan dan peraturan disuatu negara yang mengontrol perusahaan (Gillan dan Starks, 2003).

Dalam pandangan akuntansi dan literatur keuangan GCG merupakan caracara yang digunakan perusahaan untuk mendapatkan laba atas investasi mereka (Shleifer dan Vishney, 1997). FCGI 
mendefinisikan GCG sebagai peraturan yang mengatur hal-hal yang berkaitan dengan hak-hak dan kewajiban antara pemegang kepentingan intern dan ekstern lainnya (FCGI, 2000).

Konsep dasar dan praktik tata kelola di perbankan dengan di perusahaan non keuangan memiliki dua perbedaan utama. Perbedaan pertama dapat dilihat dari adanya pemangku kepentingan yang lebih banyak di perbankan daripada disektor non keuangan. Perbedaan kedua adalah adanya bisnis bank bersifat lebih kompleks dan dapat mengalami perubahan dengan cepat (Adams dan Mehran, 2003). Penerapan GCG di perbankan dilakukan sesuai dengan prinsip-prinsip yang terdiri atas transparansi, akuntanbilitas,, responsibilitas, independensi, dan kewajaran (Komite Nasional Kebijakan Governance, 2006).

\section{Peraturan Tata Kelola Perbankan Indonesia}

Pada tahun 2006 Bank Indonesia telah mengeluarkan Peraturan Bank Indonesia (PBI) Nomor 8 Tahun 2013 tentang pelaksanaan good corporate governance bagi bank umum. Peraturan tersebut dikeluarkan dengan pertimbangan bahwa semakin kompleksnya risiko bank, peningkatan kinerja bank, serta dalam rangka memperkuat kondisi internal perbankan nasional. Dalam rangka menindaklanjuti PBI tersebut secara lebih teknis, maka pada tahun 2013 di terbitkan Surat Edaran Bank Indonesia Nomor 15/15/DPNP tanggal 29 April 2013 perihal Pelaksanaan Good Corporate Governance Bagi Bank Umum.

Seiring dengan perpindahan kewenangan dari Bank Indonesia ke Otoritas Jasa Keuangan, maka pada tahun
2016 PBI Nomor 8 tahun 2013 tentang tentang pelaksanaan good corporate governance bagi bank umum dicabut dan digantikan dengan Peraturan Otoritas Jasa Keuangan Nomor (POJK) Nomor 55 Tahun 2016 Tentang Penerapan Tata Kelola bagi bank umum. Selain itu, pada tahun 2017, SEBI Nomor 15 Tahun 2013 perihal Pelaksanaan Good Corporate Governance Bagi Bank Umum dicabut dan digantikan dengan Surat Edaran Otoritas Jasa Keuangan (SEOJK) Nomor 13 /SEOJK.03/2017 Tentang Penerapan Tata Kelola Bagi Bank Umum.

Kewajiban perbankan dalam POJK Nomor 55 Tahun 2016 Tentang Penerapan Tata Kelola bagi bank umum tercantum dalam pasal 64 yang menyatakan bahwa perbankan wajib menyusun dan menyampaikan laporan pelaksanaan tata kelola pada setiap akhir tahun. POJK dalam pasal 64 juga menyebutkan bahwa salah satu hal yang harus dipenuhi dalam laporan pelaksanaan tata kelola tersebut adalah meliputi hasil penilaian sendiri oleh Bank (self-assesment) atas penerapan Tata Kelola Bank.

Lebih lanjut lagi, dalam SEOJK Nomor 13 Tahun 2017 Tentang Penerapan Tata Kelola Bagi Bank Umum Bab $X$ menyebutkan bahwa Jika penilaian sendiri oleh bank terdapat perbedaan dengan hasil penilaian penerapan tata kelola oleh OJK, maka perbankan diwajibkan untuk melakukan revisi terhadap laporan penilaian sendiri tersebut dengan segera mempublikasikan dalam laporan keuangan publikasi pada periode yang terdekat. Sebaliknya jika terdapat kesamaan hasil penilaian sendiri antara bank dengan OJK, maka tidak akan dilakukan revisi terhadap hasil penilaian sendiri oleh bank.

\section{Pengembangan Hipotesis}




\section{Pengaruh Konsentrasi Kepemilikan Saham terhadap Tata Kelola Perbankan di Indonesia}

Konsentrasi kepemilikan diperbankan dilakukan dengan membatasi jumlah pemilik saham dengan maksud mencegah dominasi pemilik atas pengurus (Sitompul, 2003). Salah satu alasan pembolehan adanya pemegang saham prioritas adalah untuk memudahkan penyelesaian ketika perusahaan mengalami masalah. Beberapa penelitian mengenai pengaruh kepemilikan terkonsentrasi terhadap informasi pengungkapan dalam laporan perusahan menunjukkan hasil bahwa konsentrasi kepemilikan yang tinggi akan meningkatkan informasi pengungkapan (Nuryaman, 2009; Sari, 2013). Peningkatan informasi pengungkapan akan meningkatkan tata kelola yang lebih baik.

Konsentrasi kepemilikan saham akan menunculkan tindakan dari pemegang saham mayoritas baik tindakan yang bersifat positif ataupun negatif bagi perusahaan. Konsentrasi kepemilikan saham memunculkan adanya pemegang saham mayoritas yang dapat melakukan pengawasan dan pengendalian yang lebih ketat terhadap biaya agensi serta pengawasan terhadap tempat berinvestasi dapt mengurangi informasi yang disembunyikan oleh pihak manajemen (Nuryaman, 2009). Adanya hal tersebut dapat meningkatkan tata kela perusahaan. Dilain sisi, kepemilikan saham yang tinggi juga dapat menyebabkan pemegang saham mayoritas dapat melakukan tindakan hanya untuk kepentingan sendiri sehingga tata kelola perusahaan akan menjadi cenderung diabaikan (Hormati, 2009).

Hasil penelitian mengenai konsentrasi kepemilikan saham terhadap tata kelola adalah berpengaruh positif yang berarti semakin besar konsentrasi kepemilikan saham maka semakin baik tata kelola perusahaan (Black dkk., 2006a; Darmawati, 2006; Durnev dan Kim, 2005; Pamungkas, 2013; Briano-Turrent \& Rodríguez-Ariza, 2016; Al-Bassam dkk, 2018). Akan tetapi terdapat penelitian yang menunjukkan bukti bahwa konsentrasi kepemilikan saham yang semakin besar maka tingkat tata kelola semakin rendah (Gillan dan Starks, 2003; Hormati, 2009; Ulum, 2007; Cunha dan Rodrigues, 2018).

\section{H1: Konsentrasi Kepemilikan berpengaruh terhadap skor tata kelola perbankan di Indonesia}

\section{Pengaruh Kebutuhan Pendanaan Eksternal Perusahaan terhadap Tata Kelola Perbankan di Indonesia}

Kebutuhan pendanaan eksternal dapat diartikan bahwa perusahaan menggunakan hutang yang tinggi untuk menghasilkan profitabilitas dan adanya hutang yang tinggi dapat meningkatkan risiko kebangkrutan (Hormati, 2009). Dampak positif dari adanya pendanaan eksternal adalah adanya pengawasan yang lebih dari pihak ketiga pemberi dana eksternal. Beberapa penelitian mengenai pengaruh kebutuhan pendanaan ekseternal terhadap tata kelola perusahaan menemukan hasil yang beragam. Durnev dan Kim (2005) Khanchel (2007), Pamungkas (2013) dan Waweru, (2014) menemukan hubungan yang positif antara kebutuhan pendanaan ekseternal terhadap tata kelola perusahaan. Sedangkan Black dkk., (2006b), Gillan dan Starks (2003) serta Puri dan Kumar (2018) menemukan hubungan yang negatif antara kebutuhan pendanaan ekseternal terhadap tata kelola perusahaan. 
H2: Kebutuhan pendanaan eksternal berpengaruh terhadap skor tata kelola perbankan di Indonesia

\section{Pengaruh Pertumbuhan Perusahaan terhadap Tata Kelola Perbankan di Indonesia}

\begin{abstract}
Perusahaan yang memiliki pertumbuhan yang pesat memiliki kebutuhan akan peningkatan tata kelola yang lebih baik untuk meningkatkan modal perusahaan (Durnev dan Kim, 2005). Dalam praktik di perbankan, pertumbuhan perusahaan dapat dilihat dari jumlah kredit yang diberikan. Semakin besar kredit yang diberikan, pendapatan dari perbankan akan semakin meningkat. Adanya peningkatan pendapatan tersebut akan meningkatkan potensi pengelolaan perusahaan yang lebih baik.
\end{abstract}

H3: Pertumbuhan perusahaan berpengaruh poistif terhadap skor tata kelola perbankan di indonesia

\section{Pengaruh Umur Perusahaan terhadap Tata Kelola Perbankan di Indonesia}

Umur perusahaan merupakan lama berdirinya suatu perusahaan. Perusahaan yang telah berdiri sejak lama dianggap mampu mengelola perusahaan dengan lebih baik. Hal tersebut juga dikarenakan pengalaman perusahaan yang telah dilalui dari awal berdiri. Pengalaman tersebut dapat digunakan untuk membuat perusahaan lebih baik dari tahun ketahun. Perusahaan yang telah lama berdiri juga dianggap telah memiliki waktu yang banyak untuk mengembangkan tata kelola yang lebih baik karena kebutuhan internal dan tututan dari investor (Biswas, 2012). Hasil penelitian terdahulu menunjukkan bahwa umur perusahaan berpengaruh meningkatkan tata kelola perusahaan (Biswas, 2012; Black dkk., 2006a; Pamungkas, 2013).
H4: Umur perusahaan berpengaruh positif terhadap skor tata kelola perbankan di indonesia

\section{Pengaruh Profitabilitas perusahaan terhadap Tata Kelola Perbankan di Indonesia}

Profitabilitas yang tinggi berdampak kepada manajer yang akan dengan terbuka terhadap informasi perusahaan dalam rangka memperoleh keunggulan kompetitif mereka, sementara perusahaan dengan profitabilitas rendah atau rugi akan cenderung kurang transparan dalam hal keuangan mereka (Inchausti, 1997). Penelitan yang dilakukan oleh Waweru (2014) menunjukkan hasil bahwa kinerja operasi yang tinggi merupakan salah satu syarat untuk penerapan tata kelola yang baik di perusahaan di Afrika dan mungkin juga untuk beberapa negara berkembang lainnya. Beberapa penelitian lainnya juga menunjukkan hasil yang sama dimana proftabilitas berpengaruh positif terhadap tata kelola perusahaan (Ariff dkk., 2007; Ehikioya, 2009; Haat dkk., 2008; Klapper dan Love, 2002; Nyamongo dan Temesgen, 2013). Selain itu, Adane, Engida, Asfaw, Azadi, \& Passel (2018) berpendapat bahwa perusahaan yang memiliki profitabilitas yang tinggi akan memerlukan tingkat pengendalian internal yang tinggi untuk mengamankan bisnis dan volume transaksi penjualan mereka selama bertahun-tahun.

H5: Profitabilitas perusahaan berpengaruh positif terhadap skor tata kelola perbankan di indonesia

\section{Pengaruh ukuran perusahaan terhadap tata kelola perbankan di Indonesia}

Perbankan yang lebih besar biasanya memiliki jumlah sumber daya keuangan dan sumber daya manusia yang lebih besar yang diperlukan dalam 
melaksanaan tata kelola yang lebih efektif (Ariff dkk., 2007; Durnev dan Kim, 2005). Selain itu, semakin besar perusahaan, biasanya memiliki fungsi manajemen risiko yang lebih baik dalam mencapai tata kelola yang baik (Franck \& Sundgren, 2012). Hasil penelitian sebelumnya (Ariff dkk., 2007; Hormati, 2009; Biswas, 2012; Khanchel, 2007; Pamungkas, 2013; Waweru, 2014; Katarachia, 2017; Adane, Engida, Asfaw, Azadi, \& Passel, 2018, Puri dan Kumar, 2018) menunjukkan bahwa semakin besar ukuran perusahaan maka tata kelola semakin baik.

H6: Ukuran perusahaan berpengaruh positif terhadap skor tata kelola perbankan di indonesia

\section{METODOLOGI PENELITIAN Populasi dan Sampel}

Populasi yang digunakan terdiri atas perbankan yang ada dengan jumlah perbankan per tahun adalah 115 perbankan. Penelitian ini menggunakan teknik purposive sampling. ini didasarkan kelengkapan data yang diperoleh untuk digunakan dalam pengujian. Data yang digunakan dalam penelitian ini merupakan jenis data sekunder yang berupa laporan tata kelola perbankan tahun 2014-2017.

Laporan tata kelola perbankan diperoleh dari website masing-masing perbankan. Kelengkapan data dalam laporan tata kelola perbankan yang dapat diperoleh selama tahun 2014-2017 adalah sebanyak 301 laporan tata kelola perbankan. Akan tetapi 2 sampel perbankan yang tidak mencantumkan laporan self-assessment tata kelola dan 5 sampel yang dikeluarkan karena outlier. Penelitian ini bersifat unbalanced panel dengan sifat times series dan cross section.

\section{Tabel 1}

\section{Kriteria Pengambilan Sampel}

\begin{tabular}{|c|l|c|c|}
\hline No & Kriteria & $\begin{array}{c}\text { Tidak } \\
\text { Memenuhi } \\
\text { Syarat }\end{array}$ & $\begin{array}{c}\text { Memenuhi } \\
\text { Syarat }\end{array}$ \\
\hline 1 & $\begin{array}{l}\text { Laporan Tata } \\
\text { Kelola Perbankan } \\
\text { yang dipublikasikan } \\
\text { di website }\end{array}$ & $\begin{array}{l}\text { - } \\
\text { nempublikasikan } \\
\text { nilai peringkat tata } \\
\text { kelola }\end{array}$ & (2) \\
\hline 3 & $\begin{array}{l}\text { Terdapat data } \\
\text { outlier (data yang } \\
\text { sangat } \\
\text { berbeda/ekstrim } \\
\text { dibandingkan } \\
\text { dengan data-data } \\
\text { lainnya) }\end{array}$ & (5) & 299 \\
\hline $\begin{array}{l}\text { Total } \\
\text { 2017) Sampel (2014- }\end{array}$ & (7) & 294 \\
\hline
\end{tabular}

sumber: data diolah, 2018

\section{Definisi Operasional Variabel}

\section{Variabel Dependen}

Penelitian ini menggunakan variabel dependen berupa tata kelola perbankan. Pengukuran tata kelola perbankan diukur dengan menggunakan skor penilaian sendiri (self assessment) perbankan. Skor penilaian sendiri (self assessment) merupakan bagian dari laporan tata kelola perbankan yang diwajibkan dalam POJK Nomor 55 Tahun 2017 Tentang Penerapan Tata Kelola bagi bank umum.

Dalam rangka memudahkan interpretasi, maka skor tata kelola dalam penelitian ini berkebalikan dengan peraturan tersebut, dimana semakin tinggi skor maka tata kelola semakin baik. Skor tata keola perbankan yang digunakan diukur dengan skala ordinal dari angka 1 sampai dengan angka 5. Penjelasan skala ordinal dari skor tata kelola perbankan dalam penelitian ini adalah sebagai berikut:

GCG = 5 "Sangat Baik"; 4 "Baik"; 3

"cukup baik"; 2 "kurang baik"; 1 "tidak baik" 


\section{Variabel Independen}

\section{Konsentrasi Kepemilikan Saham (owner)}

Kepemilkan

terkonsentrasi

merupakan kepemilikan saham yang dimiliki oleh sebagian kecil individu atau kelompok yang berakibat pemegang saham tertentu realtif dominan dengan yang lainnya (Dallas, 2004). Konsentrasi kepemilikan diukur dengan menggunakan persentase kepemilikan saham terbesar yang terkonsentrasi di perbankan.

owner = jumlah kepemilikan saham terbesar

\section{Kebutuhan Pendanaan Eksternal (leverage)}

Kebutuhan pendaan eksternal perusahaan yang digunakan dalam penelitian ini menggunakan ratio leverage dimana total kewajiban dibagi dengan total asset (Ariff dkk., 2007; Pamungkas, 2013).

leverage $=\frac{\text { Total Kewajiban }}{\text { Total Asset }}$

\section{Pertumbuhan Perusahaan (growth)}

Aktivitas utama dari perbankan adalah pemberian kredit. Oleh karena itu, pertumbuhan perusahaan dalam penelitian ini diproksikan dengan rumus kredit tahun sekarang dikurangi dengan kredit tahun lalu dan dibagi dengan kredit tahun lalu.

growth $=\frac{\text { Kredit tahun sekarang-kredit tahun lalu }}{\text { Kredit Tahun lalu }}$

Umur Perusahaan (age)
Umur perusahaan dalam penelitian ini menggunakan proksi lama berdirinya perusahaan untuk mengukur umur perusahaan (Biswas, 2012).

age = lama berdirinya perusahaan

\section{Profitabilitas (ROA)}

Profitabilitas perusahaan dapat diukur dengan menggunakan ROA dan EBIT (Waweru, 2014). Pengukuran profitabilitas ini menggunakan pengukuran yang dilakukan oleh beberap penelitian yang umum digunakan oleh berapa penelitian mengenai pengaruh profitabilitas terhadap tingkat tata kelola perusahaan (Ariff dkk., 2007; Ehikioya, 2009; Haat dkk., 2008; Klapper dan Love, 2002; Nyamongo dan Temesgen, 2013).

$\mathrm{ROA}=\frac{\text { Laba Bersih }}{\text { Total Asset }}$

Ukuran Perusahaan (asset)

asset $=$ Total Asset

Pengertian ukuran perusahaan merupakan bagian dari kapasitas tenaga kerja, kapasitas produksi dan kapasitas modal yang ada didalam perusahaan (Sari, 2013). Ukuran perusahaan dalam penelitian ini menggunakan total asset (Ariff dkk., 2007; Khanchel, 2007; Pamungkas, 2013; Waweru, 2014; Katarachia, 2017).

\section{Variabel Kontrol}

\section{Status Kepemilikan (status)}

Status kepemilikan dalam penelitian ini menggunakan dummy dimana status kepemilikan tersebut dibagi menjadi 2 
yaitu perusahaan listing dan perusahaan non listing.

\section{Teknik Analisis}

Metode analisi yang digunakan berupa analisis regresi ordinal. Penelitian ini melakukan proses pengolahan data dengan menggunakan SPSS 21. Model yang digunakan pada penelitian ini adalah sebagai berikut:

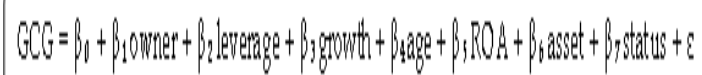

Keterangan:

GCG : skor tata kelola perusahaan owner : persentase kepemilikan saham terkonsentrasi

leverage : total kewajiban/total aset growth : kredit tahun sekarang-kredit tahun lalu)/kredit tahun lalu

age : lama berdirinya perusahaan

ROA : laba bersih/total aset

asset : total aset

status : $1=$ perbankan listing dan $0=$ perbankan non listing

\section{HASIL DAN PEMBAHASAN}

\author{
[ARIAL, 14, BOLD, UPPERCASE]
}

\section{Hasil Penelitian}

Statistik deskriptif yang terdapat pada tabel 1 menunjukkan bahwa rata-rata tingkat skor penerapan tata kelola perbankan di Indonesia adalah "4" yang menunjukkan bahwa perbankan di Indonesia sudah menerapkan tata kelola perbankan dengan baik. Selain itu dapat dilihat bahwa nilai minimum skor tata kelola adalah "2" yang berarti tidak ada perbankan yang memperoleh skor " 1 " yang menunjukkan peringkat tidak baik. Kepemilikan saham (owner) menunjukkan hasil bahwa minimal kepemilikan terpusat adalah sebesar $6 \%$ dan maksimal adalah sebesar $100 \%$ dengan rata-rata kepemilikan sebanyak $61 \%$. Hasil tersebut tidak lain dikarenakan dari sebanyak 115 perbankan yang ada di Indonesia, hanya sebanyak 43 bank atau 37\% bank yang listing di BEl sampai dengan awal tahun 2018. Tingkat leverage menunjukkan skor rata-rata sebesar $77 \%$ dengan nilai minimum sebesar $6 \%$ dan maksimum sebesar $105 \%$. Nilai minimum pertumbuhan kredit (growth) sebesar $5,1 \%$ dan maksimum sebesar $21,1 \%$ dengan rata-rata pertumbuhan kredit sebesar $15,28 \%$. Pada nilai minimum ROA pun mengalami nilai minus yang sama dengan nilai sebesar $-1,7 \%$ dan nilai maksimum sebesar $7 \%$ dengan nilai ratarata sebesar $0,83 \%$. Dari nilai growth dan ROA dapat diambil kesimpulan bahwa masih terdapat kerugian yang dialami oleh perbankan. Sedangkan umur perbankan jika dilihat dari nilai minumum yang sebesar 4 tahun dan maksimum sebesar 193 tahun dengan rata-rata sebesar 43 tahun. Hal tersebut menunjukkan bahwa perbankan di Indonesia akan terus mengalami pertumbuhan dari tahun ke tahun. Pertumbuhan perbankan dapat juga dilihat dari nilai minumum aset yaitu sebesar Rp. 231 miliar dan nilai maksimum sebesar Rp. 1.124 triliun dengan rata-rata asset perbankan sebesar Rp. 71 trilun. 


\begin{tabular}{|c|c|c|c|c|c|}
\hline Variabel & Obs & Min & Max & Mean & Std. Dev \\
\hline GCG & 294 & 2,00 & 5,00 & 3,8299 & 0,55882 \\
\hline Owner & 294 & 0,06 & 1,00 & 0,6155 & 0,25306 \\
\hline Leverage & 294 & 0,06 & 1,05 & 0,7703 & 0,22426 \\
\hline Growth & 294 & $-0,51$ & 2,11 & 0,1528 & 0,26682 \\
\hline Age & 294 & 4,00 & 193,00 & 43,2585 & 24,46913 \\
\hline ROA & 294 & $-0,17$ & 0,07 & 0,0083 & 0,02111 \\
\hline Asset (jutaan) & 294 & 231.002 & 1.124 .700 .847 & 71.585 .206 & 169.068 .776 \\
\hline Status & 294 & 0,00 & 1,00 & 0,4320 & 0,49620 \\
\hline
\end{tabular}

Hasil statistik distribusi frekuensi pada tabel 2 menunjukkan bahwa nilai skor tata kelola perbankan didominasi oleh nilai baik dengan jumlah perbankan sebanyak 203 perbankan atau sebanyak 69\% dari 294 sampel perbankan. Nilai skor sangat baik memperoleh frekuensi sebanyak 22 atau $7,5 \%$ dari 294 sampel perbankan. Nilai skor cukup baik memperoleh frekuensi sebanyak 66 atau 22,4\% dari 294 sampel perbankan. Sedangkan nilai skor kurang baik hanya mendapatkan frekuensi sebanyak 3 atau 1\% dari 294 sampel perbankan serta untuk nilai skor tidak baik tidak ada perbankan yang mendapatkan skor tersebut. Berdasarkan penjelasanpenjelasan tersebut dapat disimpulkan bahwa perbankan telah menerapkan tata kelola perbankan yang baik. Variabel status kepemilikan (status) dalam tabel 2 menunjukkan bahwa dari sampel 294 perusahaan terdapat 167 perusahaan non listing atau 56,8\% dengan nilai skor GCG terbanyak pada skor "4" atau baik sebanyak 97 laporan tata kelola perbankan dan 127 perusahaan listing atau sebanyak $43,2 \%$. dengan nlai GCG terbanyak pada skor "4" atau baik sebanyak 106 laporan tata kelola perbankan.
Tabel 1

Hasil Statistik Deskriptif Sumber: Data diolah, 2018

\begin{tabular}{|c|c|c|c|c|c|}
\hline $\begin{array}{l}\text { Var } \\
\text { iab } \\
\text { el }\end{array}$ & Group & $\begin{array}{l}\text { Fre } \\
\text { kue } \\
\text { nsi }\end{array}$ & $\begin{array}{l}\text { Per } \\
\text { sen } \\
(\%)\end{array}$ & $\begin{array}{c}\mathbf{N} \\
0 \\
\mathrm{n} \\
\mathrm{Li} \\
\text { st } \\
\text { in } \\
\mathrm{g}\end{array}$ & $\begin{array}{l}\text { Li } \\
\text { sti } \\
\text { ng }\end{array}$ \\
\hline $\begin{array}{l}\mathrm{G} \\
\mathrm{C}\end{array}$ & $\begin{array}{l}1 \text { "tidak } \\
\text { baik" }\end{array}$ & 0 & 0 & 0 & 0 \\
\hline \multirow[t]{4}{*}{$\mathrm{G}$} & $\begin{array}{l}2 \\
\text { "kuran } \\
\text { g baik" }\end{array}$ & 3 & 1 & 3 & 0 \\
\hline & $\begin{array}{l}3 \\
\text { "cukup } \\
\text { baik" }\end{array}$ & 66 & 22,4 & 16 & 50 \\
\hline & $\begin{array}{l}4 \\
\text { "baik" }\end{array}$ & 203 & 69 & 97 & 106 \\
\hline & $\begin{array}{l}5 \\
\text { "Sanga } \\
\text { t baik" }\end{array}$ & 22 & 7,5 & 11 & 11 \\
\hline \multicolumn{2}{|c|}{ Jumlah } & 294 & 100 & $\begin{array}{c}16 \\
7\end{array}$ & 127 \\
\hline
\end{tabular}


Hasil statistik distiribusi pengungkapan skor GCG pada tabel 3 menunjukkan bahwa pada tahun 2014 sebanyak 77 perbankan mengungkapkan skor GCG dan sebanyak 38 perbankan tidak mengungkapan skor GCG dalam laporan tata kelola perbankan mereka. Pada tahun 2015 sebanyak 84 perbankan mengungkapan mengungkapkan skor GCG dan dan sebanyak 31 perbankan tidak mengungkapan skor GCG dalam laporan tata kelola perbankan mereka. Pada tahun 2016 sebanyak 100 perbankan mengungkapkan skor GCG dan sebanyak 15 perbankan tidak mengungkapan skor GCG dalam laporan tata kelola perbankan mereka Pada tahun 2017 sebanyak 33 perbankan mengungkapkan skor GCG dan sebanyak 82 perbankan tidak mengungkapan skor GCG dalam laporan tata kelola perbankan mereka. Berdasarkan hal tersebut dapat disimpulkan bahwa terdapat ketidakkonsistenan perbankan dalam mengungkapan skor GCG yang merupakan kewajiban minimum dalam laporan tata kelola perbankan.

\begin{tabular}{c} 
Tabel 3 \\
Hasil Statistik Distribusi \\
Pengungkapan Skor GCG \\
\hline
\end{tabular}
Tahun

\begin{tabular}{lcccc} 
Keterangan & $\mathbf{2 0 1}$ & $\mathbf{2 0 1}$ & $\mathbf{2 0 1}$ & $\mathbf{2 0 1}$ \\
& $\mathbf{4}$ & $\mathbf{5}$ & $\mathbf{6}$ & $\mathbf{7}$ \\
\hline $\begin{array}{l}\text { Mengungkap } \\
\text { kan }\end{array}$ & 77 & 84 & 100 & 33 \\
$\begin{array}{l}\text { Tidak } \\
\text { Mengungkap } \\
\text { kan }\end{array}$ & 38 & 31 & 15 & 82 \\
$\begin{array}{l}\text { Jumlah } \\
\text { Sumber: Data diolah, 2018 }\end{array}$ & $\mathbf{1 1 5}$ & $\mathbf{1 1 5}$ & $\mathbf{1 1 5}$ & $\mathbf{1 1 5}$ \\
\hline
\end{tabular}

\section{Hasil Regresi}

Hasil analisis regresi pada tabel 4 dibawah ini menunjukkan bahwa model fitting information signifikan pada taraf $5 \%$ (sign 0,000). Goodness menunjukkan bahwa nilai pearson dan deviance berada dalam taraf signifikansi $>0,5 \%$. Hal tersebut menunjukkan bahwa model dalam penetian ini sesuai dengan data empiris atau model layak untuk digunakan. Nilai pseudo R-Square menunjukkan nilai sebesar 0,142 atau $14,2 \%$. Nilai tersebut menunjukkan bahwa variabel independen mampu menjelaskan variabel dependen sebesar $14,2 \%$ dan sisanya sebesar $85,8 \%$ dipengaruhi oleh variabel lain.

Hasil analisis regresi pada tabel 4 jika dibandingkan dengan hipotesis dalam penelitian ini menunjukkan bahwa variabel kepemilikan saham terkonsentrasi (owner), kebutuhan pendanaan eksternal (leverage), profitabilitas (ROA), ukuran perusahaan (asset) status kepemilikan (status) sesuai dengan hipotesis yang telah diuraikan. Sedangkan pada variabel pertumbuhan (growth) dan umur (age) menunjukkan hasil yang tidak sesuai dengan hipotesis yang telah diuraikan. Variabel kepemilikan saham terkonsentrasi (owner) menunjukkan pengaruh positf dan signifikan pada level < $1 \%$ (sig. 0,000). Variabel leverage menunjukkan pengaruh negatif dan signifikan pada level <5\% (sig. 0,028). Variabel ukuran perusahaan (asset) menunjukkan pengaruh negatif dan signifikan pada level $<5 \%$ (sign. 0,013). Variabel growth dan age menunjukkan pengaruh positif dan tidak signifikan. Variabel kontrol berupa status kepemilikan (status) menunjukkan pengaruh positif dan signifikan pada level $<1 \%$ (sig. 0,000 dan sig. 0,002). Berikut ini adalah tabel hasil regresi penelitian dengan menggunakan analisis regresi ordinal: 
Tabel 4

Hasil Analisis Regresi Ordinal

\begin{tabular}{lllll}
\hline Variabel & Uji & Hipotesis & Estimate & Prob \\
\hline Owner & $\mathrm{H} 1$ & $(-/+)$ & 2,140 & $0,000^{* \star *}$ \\
Leverage & $\mathrm{H} 2$ & $(-/+)$ & $-1,476$ & $0,028^{\star \star}$ \\
Growth & $\mathrm{H} 3$ & $(+)$ & 0,596 & 0,257 \\
Age & $\mathrm{H} 4$ & $(+)$ & 0,005 & 0,423 \\
ROA & $\mathrm{H} 5$ & $(+)$ & 32,443 & $0,000^{\star * \star}$ \\
Asset & $\mathrm{H} 6$ & $(+)$ & 0,282 & $0,013^{\star *}$ \\
Status & & $(+)$ & 1,078 & $0,002^{\star \star *}$ \\
\hline
\end{tabular}

Model Fitting Information: 0,000; Goodness-of-Fit: Pearson 0,513; Deviance 1,000; Pseudo R-Square: 0,142; Test of Parallel Lines: 0,210

${ }^{* * *}$ sign. $1 \% ;{ }^{* *}$ sign. $5 \% ;{ }^{*} \operatorname{sign} .10 \%$

\section{Sumber: Data diolah, 2018}

\section{Pembahasan}

Hasil penelitian pada hipotesis pertama dapat dilihat bahwa kepemilikan saham terkonsentrasi berpengaruh positif terhadap skor tata kelola perbankan. Hal tersebut menunjukkan arti bahwa semakin tinggi kepemilikan saham terkonsentrasi maka semakin tinggi skor tata kelola perbankan yang berarti semakin baik tata kelola perbankan. Kepemilikan saham terkonsentrasi yang masih banyak ditemui diperbankan dikarenakan sebanyak 31 perbankan di Indonesia merupakan perbankan milik pemerintah pusat dan pemerintah daerah. Hasil hipotesis pertama tersebut sejalan dengan beberapa penelitian (Black dkk., 2006a; Darmawati, 2006; Durnev dan Kim, 2005; Pamungkas, 2013; Al-Bassam dkk, 2018).

Hasil penelitian pada hipotesis kedua dapat dilihat bahwa leverage berpengaruh negatif terhadap skor tata kelola perbankan yang berarti semakin jelek tata kelola perbankan. Leverage yang tinggi menunjukkan bahwa kebutuhan pendanaan yang tinggi dari pihak eksternal. Kebutuhan pendanaan tinggi yang berasal dari hutang menunjukkan bahwa perusahaan kurang dapat menghasilkan aktiva yang liquid yang berakibat kepada aktivitas perusahaan akan tergangu dan tingkat tata kelola menjadi rendah. Hasil hipotesis kedua tersebut sejalan dengan dengan penelitian Gillan dan Starks (2003) serta Franck \& Sundgren (2012).

Hasil penelitian pada hipotesis ketiga dan keempat berupa pertumbuhan (growth) dan umur perusahaan (age) tidak berpengaruh terhadap skor tata kelola perbankan. Hasil penelitian hipotesis kedua tersebut sejalan dengan penelitian yang dilakukan oleh (Puri dan Kumar, 2018). Hasil penelitian pada hipotesis kelima dalam penelitian ini menunjukkan bahwa profitabilitas (ROA) berpengaruh positif terhadap skor tata kelola perbankan. Hal tersebut berarti semakin tinggi profitabilitas (ROA) maka semakin tinggi skor tata kelola perbankan yang berarti semakin baik tata kelola perbankan. Hasil pengujian profitabilitas (ROA) tersebut sesuai dengan penelitian Waweru (2014).

Hasil penelitian pada hipotesis keenam dalam penelitian ini menunjukkan bahwa ukuran perusahaan (asset) berpengaruh positif terhadap skor tata kelola perbankan. Hal tersebut berarti 
semakin tinggi ukuran perusahaan (asset) maka semakin tinggi skor tata kelola perbankan yang berarti semakin baik tata kelola perbankan. Semakin besar ukuran perusahaan maka kompleksitas operasi akan semakin tinggi, sehingga salah satu cara untuk mengatasi kompleksitas tersebut adalah dengan meningkatkan tata kelola perusahaan (Hormati, 2009). Hasil pengujian ukuran perusahaan (asset) tersebut sesuai dengan beberapa penelitian sebelumnya (Ariff dkk., 2007; Biswar, 2012; Khanchel, 2007; Hormati, 2009; Pamungkas, 2013; Waweru, 2014; Katarachia, 2017; Puri dan Kumar, 2018).

Variabel kontrol berupa status kepemilikan dalam penelitian ini menunjukkan hubungan yang positif. Hal tersebut berarti perbankan yang dikategorikan telah listing dalam Bursa Efek Indonesia (BEI) cenderung memiliki tata kelola yang lebih baik daripada perusahaan yang belum listing dalam BEl. Adanya kecenderungan tata kelola yang lebih baik dimungkinkan karena adanya tuntutan bahwa perusahaan harus terlihat dikelola dengan baik di pasar saham agar pergerakan saham perusahaan yang bersangkutan tidak mengalami penurunan harga saham. Hasil pengujian variabel kontrol sejalan dengan penelitian yang dilakukan oleh Puri dan Kumar (2018).

\section{KESIMPULAN}

Penelitian ini dapat diambil kesimpulan bahwa hampir sebagian besar tingkat penerapan tata kelola perbankan sudah baik dengan rata-rata skor pengungkapan "4". Hal penelitian ini juga menunjukkan hasil bahwa semakin besar kepemilikan saham terkonsentrasi (owner), profitabilitas (ROA), ukuran perusahaan (asset), dan status kepemilikan (status) maka semakin tinggi tingkat tata kelola perbankan. Sebaliknya, leverage dalam penelitian ini menunjukkan hasil dimana semakin tinggi leverage makan semakin rendah tingkat tata kelola perbankan. Pengujian pertumbuhan (growth) dan umur perusahaan (age) tidak berpengaruh terhadap tingkat tata kelola perbankan.

\section{IMPLIKASI, KETERBATASAN, DAN SARAN}

\section{Keterbatasan}

Penelitian ini dilakukan dengan beberapa keterbatasan, yang dengan keterbatasan tersebut berpengaruh terhadap hasil penelitian. Keterbatasan dan batasan dalam penelitian ini adalah sebagai berikut:

a. Penelitian ini menggunakan variabel dependen berupa skor tata kelola perbankan berdasarkan penilaian sendiri (self assessment). pengukuran variabel dependen tersebut menyebabkan peneliti tidak bisa melihat dengan detail berapa total pengungkapan pelaksanaan tata kelola perbankan per item dari 11 faktor penilaian tata kelola yang telah dijelaskan dalam POJK dan SEOJK tentang Penerapan Tata Kelola Bagi Bank Umum.

b. Penelitan ini masih terbatas dengan menggunakan empat variabel independen yang secara umum variabel tersebut sudah sering digunakan dalam penelitian yang menggunakan data laporan keuangan perusahaan.

\section{Implikasi}

a. Hasil tingkat tata kelola perbankan dari tahun 2014-2017 berada dalam skor "4" yang berarti tingkat tata kelola perbankan sudah baik. Hasil tersebut diharapkan dapat bertahan dan dapat meningkat ditahun 2018. 
b. Hasil penelitian ini menunjukkan bahwa tidak adanya konsistensi dari perbankan yang ada di Indonesia untuk melampirkan hasil self assessment tata kelola yang telah di verifikasi oleh OJK dalam laporan tata kelola perbankan. Hal tersebut dapat dilihat dari kenaikan atau penurunan pengungkapan skor pengungkapan self assessment tata kelola dari tahun 2014-2017.

c. Pengungkapan hasil self assessment tata kelola yang telah di verifikasi oleh OJK merupakan bagian dari kewajiban yang telah diatur dalam peraturan OJK. Mengingat hal tersebut, maka OJK diharapkan dapat memberikan sanksi yang tegas apabila perbankan tidak mematuhi kewajiban tersebut.

\section{Saran}

a. Diharapkan adanya peningkatan kesadaran pengungkapan dan peningkatan skor hasil self assessment tata kelola perbankan.

b. Penelitian selanjutnya diharapkan menggunakan pengukuran variabel dependen dengan menggunakan kertas kerja penilaian sendiri (self assessment) yang ada dalam POJK dan SEOJK tentang Penerapan Tata Kelola Bagi Bank Umum. Penggunaan pengukuran tersebut diharapkan dapat melihat dengan lebih detail item-item mana saja yang telah diterapkan oleh perbankan dalam tata kelola mereka. Adanya item yang lebih detail akan membuat peneliti selanjutnya dapat melihat apakah terdapat adanya gap dan tren yang jelas dari pengungkapan item pelaksanaan tata kelola dari masingmasing perbankan.

c. Penelitian selanjutnya juga diharapkan menggunakan variabel independen yang lebih bervariatif dari penelitian ini. Penelitian selanjutnya dapat menambahkan variabel komite audit (Bhasin, 2012), kualitas audit eksternal (Hormati, 2009; Waweru, 2014; Cunha dan Rodrigues, 2018), ukuran dewan komisaris dan intengible asset (Khanchel, 2007) serta risiko perusahaan (Black dkk., 2006a) sebagai variabel independen.

\section{REFERENCES}

Adams, R. B. (2009). Governance of Banking Institutions. In Corporate Governance (pp. 1-28).

Adams, R., \& Mehran, H. (2003). Is corporate governance different for bank holding companies? Economic Policy Review, 9(1), 123-142. Retrieved from https://papers.ssrn.com/sol3/papers. cfm?abstract_id=387561

Adane, Y. G., Engida, T. G., Asfaw, Y. A., Azadi, H., \& Passel, S. Van. (2018). Determinants of internal governance quality: Evidence from corporations in Ethiopia. Cogent Economics \& Finance, $\quad 6(1), \quad 1-17$. https://doi.org/10.1080/23322039.20 18.1537051

Ali, S., Liu, B., \& Su, J. J. (2018). Does corporate governance quality affect default risk? The role of growth opportunities and stock liquidity. International Review of Economics and Finance, 58, 422-448. https://doi.org/10.1016/j.iref.2018.05. 003

Ariff, A. M., Ibrahim, M. K., \& Othman, R. (2007). Determinants of firm level governance: Malaysian evidence. Corporate Governance, 7(5), 562573.

https://doi.org/10.1108/14720700710 827158

Baskoro, H. (2017). Pengaruh Corporate Governance Perception Index Terhadap Nilai Perusahaan. Retrieved from http://eprints.undip.ac.id/53248/ 
Bauer, R., Guenster, N., \& Otten, R. (2004). Empirical Evidence on Corporate Governance in Europe: The Effect on Stock Returns, Firm Value and Performance. Journal of Asset Management, 5(2), 91-104. https://doi.org/10.1057/palgrave.jam. 2240131

Bhasin, M. L. (2012). Audit Committee Mechanism to Improve Corporate Governance: Evidence from a Developing Country. Modern Economy, 03(07), 856-872. https://doi.org/10.4236/me.2012.371 09

Biswas, P. K. (2012). Corporate Governance Reforms in Emerging Countries: A Case Study of Bangladesh. International Journal of Disclosure and Governance. https://doi.org/10.1057/jdg.2013.31

Black, B. S., Jang, H., \& Kim, W. (2006a). Does Corporate Governance Predict Firms' Market Values? Evidence From Korea. Journal of Law, Economics, and Organization, 22(2), 366-413.

https://doi.org/10.1093/jleo/ewj018

Black, B. S., Jang, H., \& Kim, W. (2006b). Predicting firms Corporate Governance Choices: Evidence from Korea. Journal of Corporate Finance, 12(3), 660-691. https://doi.org/10.1016/j.jcorpfin.2005 .08 .001

Brown, L. D., \& Caylor, M. L. (2006). Corporate Governance and Firm Valuation. Journal of Accounting and Public Policy, 25(4), 409-434. https://doi.org/10.1016/j.jaccpubpol.2 006.05.005

Cadbury, A. (1992). The Financial Aspects of Corporate Governance. The
Committee on the Financial Aspects of Corporate Governance, UK. https://doi.org/ISBN 0852589131

Dallas, G. (2004). Governance and Risk: An Analytical Handbook for Investor, Managers, Directors, and Stakeholders. New York: mcGrawHill.

Darmawati. (2006). Pengaruh Karakteristik Perusahaan dan Faktor Regulasi terhadap Kualitas Implementasi Corporate Governance. In Simposium Nasional Akuntansi. IX. Padang.

Durnev, A. R. T., \& Kim, E. H. A. N. (2005). To Steal or Not to Steal: Firm Attributes, Legal Environment, and Valuation. The Jorunal of Finance, 55(3), 1461-1493.

Ehikioya, B. I. (2009). Corporate Governance Structure and Firm Performance in Developing Economies: Evidence from Nigeria. Corporate Governance: The International Journal of Business in Society, $\quad 9(3), \quad 231-243$. https://doi.org/10.1108/14720700910 964307

FCGI. (2000). Peranan Dewan Komisaris dan Komite Audit dalam Pelaksanaan Corporate Governance (Tata Kelola Perusahaan). Retrieved from www.fcgi.or.id

Franck, P., \& Sundgren, S. (2012). Determinants of internal governance quality: Evidence from Sweden. Managerial Auditing Journal, 27(7), 639-665.

https://doi.org/10.1108/02686901211 246796

Gillan, S., \& Starks, L. (2003). Corporate Governance, Corporate Ownership, 
and the Role of Institutional Investors: A Global Perspective. Journal of Applied Finance, 2(13), 4-22. Retrieved from http://webkuliah.unimedia.ac.id/eboo k/files/gillan(inst-investors).pdf

Haat, M. H. C., Rahman, R. A., \& Mahenthiran, S. (2008). Corporate Governance, Transparency and Performance of Malaysian Companies. Managerial Auditing Journal (Vol. 23). https://doi.org/10.1108/02686900810 899518

Hikmah, N., Chairina, \& Rahmayanti, D. (2011). Faktor-Faktor Yang Mempengaruhi Luas Pengungkapan Corporate Governance Dalam Laporan Tahunan Perusahaan Perbankan Yang Terdaftar Di Bursa Efek Indonesia. In Ikatan Akuntan Indonesia (Ed.), Simposium Nasional Akuntansi XIV. Ikatan Akuntan Indonesia.

Hormati, A. (2009). Karakteristik Perusahaan Terhadap Kualitas Implementasi Corporate Governance. Jurnal Keuangan Dan Perbankan, 13(2), 288-298.

Inchausti, B. G. (1997). The influence of company characteristics and accounting regulation on information disclosed by Spanish firms. European Accounting Review, 6(1), 45-68. https://doi.org/10.1080/09638189733 6863

Irmalasari. (2010). Pengaruh Mekanisme Good Corporate Governance Terhadap Kinerja Perbankan Nasional.

Khanchel, I. (2007). Corporate Governance: Measurement and Determinant Analysis. Managerial
Auditing Journal, 22(8), 740-760. https://doi.org/10.1108/02686900710 819625

Klapper, L. F., \& Love, I. (2002). Corporate Governance, Investor Protection, and Firm Performance in Emerging Markets. Journal of Corporate Finance, 10(April), 703-728. https://doi.org/10.1080/17938120.20 14.886421

Komite Nasional Kebijakan Governance. (2006). Pedoman Umum Good Corporate Governance Indonesia. Pedoman Umum Good Corporate Governance Indonesia, 30. Retrieved from www.governanceindonesia.or.id

Larastomo, J., Perdana, H. D., Triatmoko, H., \& Sudaryono, E. A. (2016). Pengaruh Tata Kelola Perusahaan dan Penghindaran Pajak Terhadap Manajemen Laba Pada Perusahaan Manufaktur di Indonesia. Esensi: Jurnal Bisnis Dan Manajemen, 6(1), 63-74.

https://doi.org/10.15408/ess.v6i1.312 1

Makki, M. A. M., \& Lodhi, S. A. (2014). Impact of Corporate Governance on Intellectual Capital Efficiency and Financial Performance. Pakistan Journal of Commerce and Social Sciences, 8(2), 305-330.

Nuryaman. (2009). Pengaruh Konsentrasi Kepemilikan, Ukuran Perusahaan, dan Mekanisme Corporate Governance Terhadap Pengungkapan Sukarela. Jurnal Akutansi Dan Keuangan Indonesia, 6(1), 89-116. Retrieved from http://siloamhospitals.com/investorrelations/corporate-governance12.html 
Nuswandari, C. (2009). Pengaruh Corporate Governance Index Terhadap Kinerja Perusahaan Pada Perushaan yang Terdaftar di Bursa Efek Indonesia. Bisnis Dan Ekonomi, 16(2), 70-84.

Nyamongo, E. M., \& Temesgen, K. (2013). The effect of governance on performance of commercial banks in Kenya: a panel study. Corporate Governance: The International Journal of Business in Society, 13(3), 236-248.

Pamungkas, I. (2013). Analisis FaktorFaktor Mempengaruhi Good Corporate Governance.

Ramadhani, S., Andreas, \& Desmiyawati. (2015). Pengaruh Corporate Governance Perception Index dan Kebijakan Hutang terhadap Nilai Perusahaan dengan Kebijakan Dividen sebagai Variabel Intervening. Jurnal Akuntansi, 4(1), 1-17.

Sari, J. F. (2013). Pengaruh Corporate Governance, Konsentrasi Kepemilikan dan Ukuran Perusahaan Terhadap Pengungkapan Enterprise Risk Management (Studi Empiris pada Perusahaan Manufaktur yang Terdaftar di BEI Tahun 2010-2011).

Shleifer, A., \& Vishney, R. W. (1997). Survey of Corporate Governance.Pdf. Journal of Finance, 52(2), 737-783. https://doi.org/10.1111/j.15406261.1997.tb04820.x

Sihombing, J., \& Pangaribuan, H. (2017). Disclosure And Information Asymmetry In Indonesia Banking Industry. Jurnal Akuntansi, 11(2),
156-169. Retrieved from http://ecojoin.org/index.php/EJA/artic le/view/192

Sitompul. (2003). Pembatasan Kepemilikan Bank Gagasan Untuk Memperkuat Sistem Perbankan. Jurnal Hukum Bisnis, 22(6), 1-12.

Suharna, A., \& Swandari, F. (2017). Pengaruh Corporate Governance Perception Index Terhadap Kinerja perusahaan dalam Masa Krisis Ekonomi Global. Jurnal Wawasan Manajemen, 1(1), 129-152. Retrieved from http://jwm.ulm.ac.id/id/index.php/jwm /article/view/64

Ulum. (2007). Pengaruh Karakteristik Perusahaan terhadap Kualitas Implementasi Good Corporate Governance. Universitas Brawijaya.

Waweru, N. M. (2014). Determinants of Quality Corporate Governance in Sub-Saharan Africa. Managerial Auditing Journal, 29(5), 455-485. https://doi.org/10.1108/EL-01-20170019

Wibowo, E. (2010). Implementasi Good Corporate Governance di Indonesia. Jurnal Ekonomi Dan Kewirausahaan, 10(2), 129-138.

Wijayanti. (2012). Pengaruh Penerapan Corporate Governance Terhadap Kinerja Keuangan Pada Perusahaan Perbankan Yang Terdaftar di Bursa Efek Indonesia (BEI) Tahun 20092011. Universitas Diponegoro. 